\title{
E-VOTING BERBASIS WEBSITE PADA PEMILIHAN KADES DI RANTAU JAYA (LAKE) DENGAN KEAMANAN DATA MENGGUNAKAN ENKRIPSI BASE 64
}

\author{
Harma Oktafia Lingga Wijaya \\ STMIK MUSIRAWAS, Sumatera Selatan-Indonesia \\ Jalan Jend.Besar H.M Soeharto Kel. Lubuk kupang Kec. Lubuklinggau Selatan I Kota \\ Lubuklinggau Sumatera Selatan \\ Harmaoktafialingga@gmail.com
}

\begin{abstract}
The world of technology and science at this time is growing rapidly, resulting in many changes that occur in human life. Thus, with the development of this technology every work will be realized more efficiently and effectively. Information Systems made to facilitate the management and storage of data it can produce a precise and accurate information. Currently a form of information and data can be made in accordance with what we want, and many opportunities that can be exploited to develop it. From the above information, to overcome perkembanagn existing technology it is necessary to create a website-based information system, is expected to facilitate the delivery of information and minimize fraud, e-voting refers to the process of utilization of electronic devices to further support the smooth process and also the automation model that allows intervention At least from individuals in all processes. The electoral system in this village still uses the conventional electoral system, the voting process and the vote count in the conventional election are still many weaknesses among them is the wrong voters in terms of marking on the ballot paper, because the provisions of the validity of the marking is less clear that many sound cards are in And the second is on the announcement of the results of the slow election because it must perform calculations manually and often fraud, and data equality is very important in this system because the election is a crucial problem in the community so that the necessary security of data election results tersebutmaka in The data security researchers use base 64 encryption.
\end{abstract}

Keywords: E-votting, village head election, encryption base 64

Abstrak
Dunia teknologi dan ilmu pengetahuan pada saat ini berkembang pesat,
mengakibatkan banyak perubahan yang terjadi dalam kehidupan manusia. Maka,
dengan adanya perkembangan teknologi ini setiap pekerjaan akan dapat
direalisasikan secara lebih efisien dan efektif. Sistem Informasi dibuat untuk
mempermudah dalam pengelolaan dan penyimpanan data maka dapat
menghasilkan suatu informasi yang tepat dan akurat. Saat ini suatu bentuk
informasi dan data bisa dibuat sesuai dengan apa yang kita inginkan, dan banyak
peluang yang bisa dimanfaatkan untuk mengembangkannya. Dari keterangan diatas,
untuk megatasi perkembanagn teknologi yang ada maka perlu dibuat sistem
informasi berbasis website, diharapkan dapat mempermudah penyampaian
E-Voting Berbasis Website (Harma Oktafia Lingga Wijaya)|48


informasi dan meminimalisir kecurangan, e-voting lebih mengacu pada proses pemanfaatan perangkat elektronik untuk lebih mendukung kelancaran proses dan juga model otomatisasi yang memungkinkan campur tangan minimal dari individu dalam semua prosesnya. Sistem pemilihan pada desa ini masih menggunakan sistem pemilihan konvensional, proses pemungutan dan penghitungan suara secara pemilihan konvensional tersebut masih banyak mempunyai kelemahan diantaranya adalah pemilih salah dalam hal memberi tanda pada kertas suara, karena ketentuan keabsahan penandaan yang kurang jelas sehingga banyak kartu suara yang yang di nyatakan tidak sah, dan yang kedua yaitu pada pengumuman hasil pemilihan yang lambat karena harus melakukan perhitungan secara manual dan sering terjadi kecurangan, dan keamaan data sangat penting didalam sistem ini karena pemilihan merupakan masalah krusial dimasyarakat sehingga diperlukan pengamanan terhadap data hasil pemilihan tersebut.maka dalam keamana datanya peneliti menggunakan enkripsi base 64 .

Kata kunci: E-votting, pemilihan kepala desa, enkripsi base 64

\section{PENDAHULUAN}

Perkembangan Perkembangan teknologi informasi saat ini mengharuskan setiap perusahaan untuk dapat meningkatkan kualitas kinerjanya dalam upaya menghadapi persaingan global yang semakin pesat. Perusahaan dan pelanggan tidak lagi dibatasi oleh jarak dan waktu dimana semuanya dilakukan melalui media website dalam internet. Seiring penggunaannya yang semakin luas menimbulkan sebuah kejahatan yang disebut dengan "cybercrime". Kejahatan tersebut seperti mencuri pin kartu kredit, menyadap data pribadi seseorang seperti alamat email, atau memanipulasi informasi dari sebuah halaman website dengan tujuan untuk mendapatkan apa yang diinginkannya.

Menurut Badan Penelitian dan Penerapan Teknologi (BPPT), E-Voting merupakan sistem untuk membuat surat suara, memberikan, menghitung, menayangkan perolehan suara, serta menghasilkan dan memelihara jejak audit secara elektronik dan digital. Pemahaman tentang $e$-voting lebih mengacu pada proses pemanfaatan perangkat elektronik untuk lebih mendukung kelancaran proses dan juga model otomatisasi yang memungkinkan campur tangan minimal dari individu dalam semua prosesnya.

Desa Rantau Jaya (Lake) adalah sebuah desa pada kecamatan Karang Jaya Kabupaten Musi Rawas Utara, dengan letak geografis berada pada garis lintang 2.8513807 dan garis bujur 102.8111672, Sistem pemilihan pada desa ini masih menggunakan sistem pemilihan konvensional, proses pemungutan dan penghitungan suara secara pemilihan konvensional tersebut masih banyak mempunyai kelemahan diantaranya adalah pemilih salah dalam hal memberi tanda pada kertas suara, karena ketentuan keabsahan penandaan yang kurang jelas sehingga banyak kartu suara yang yang di nyatakan tidak sah, dan yang kedua yaitu pada pengumuman hasil pemilihan yang lambat karena harus melakukan perhitungan secara manual dan sering terjadi kecurangan, dan keamaan data sangat penting didalam sistem ini karena pemilihan merupakan masalah krusial dimasyarakat sehingga diperlukan pengamanan terhadap data hasil pemilihan tersebut.Berdasarkan hal tersebut maka penelitian ini dilakukan untuk membangun suatu aplikasi yang bisa mengatasi masalah diatas dengan menerapkan solusi $e$ - 
voting memadukan berbasis web dengan kemananan data menggunakan enkripsi Base64,

\section{METODOLOGI PENELITIAN}

\subsection{Defenisi Aplikasi}

Aplikasi adalah penggunaan dalam suatu komputer,instruksi (instructiom) atau pernyataan (statement) yang disusun sedemikian rupa sehingga komputer dapat memproses input menjadi output [1].

\subsection{Defenisi E-Voting}

Menurut Badan Penelitian dan Penerapan Teknologi (BPPT), E-Voting merupakan sistem untuk membuat surat suara, memberikan, menghitung, menayangkan perolehan suara, serta menghasilkan dan memelihara jejak audit secara elektronik dan digital [2].

\subsection{Enkripsi Base64}

Enkripsi adalah proses mengamankan suatu informasi dengan membuat informasi tersebut tidak dapat dibaca tanpa bantuan pengetahuan khusus, keuntungan dari enkripsi adalah kode asli kita tidak dapat dibaca oleh orang lain. Proses utama dalam suatu algoritma kriptografi adalah enkripsi dan dekripsi [3].

\subsection{Defenisi Keamanan Data}

Keamanan merupakan komponen yang vital didalam komunikasi elektronis. Masih banyak yang belum menyadari bahwa keamanan (security) merupakan sebuah komponen penting yang tidak murah. Teknologi kriptografi sangat berperan juga dalam proses komunikasi yang digunakan untuk melakukan enkripsi (pengacakan) data yang di transaksikan selama perjalanan dari sumber sampai tujuan dan juga melakukan dekripsi (menyusun kembali) data yang telah teracak tersebut [4].

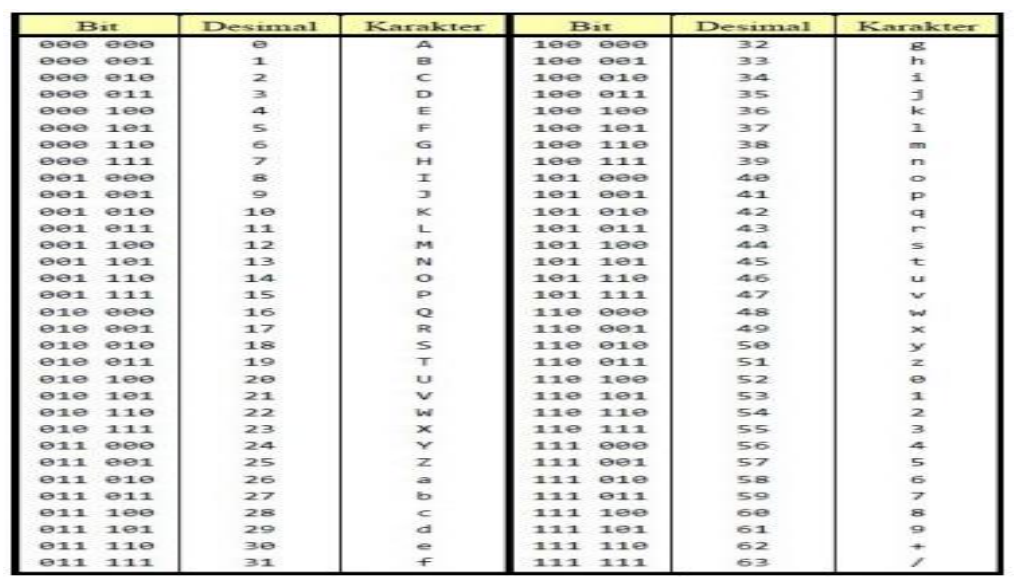

Gambar 1. Tabel Ascii Base 64

\subsection{Metode Penelitian}

Adapun metode yang digunakan dalam penelitian ini yaitu menggunakan Metode penelitian deskriptif. Metode penelitian deskriptif adalah salah satu metode penelitan yang banyak digunakan pada penelitian yang bertujuan untuk 
menjelaskan suatu kejadian. penelitian desktiptif adalah sebuah penelitian yang bertujuan untuk memberikan atau menjabarkan suatu keadaan atau fenomena yang terjadi saat ini dengan menggunakan prosedur ilmiah untuk menjawab masalah secara aktual.

\section{HASIL DAN PEMBAHASAN}

Dengan analisis dan desain sistem yang ada, maka dirancanglah sebuah aplikasi E-Voting Pemilihan Kades di Desa Rantau jaya menggunakan UML (Unified Modelling Language) yang terdiri dari Use Case Diagram, Activity Diagram, Sequence Diagram dan Class Diagram untuk menghasilkan system yang lebih baik. Proses yang dirancang kemudia diuraikan menjadi beberapa bagian yang dapat membentuk system tersebut menjadi satu kesatuan komponen.

\subsection{Use Case Diagram}

Use case diagram memperlihatkan hubungan yang terjadi antara setiap aktor dengan use case yang terdapat dalam sistem.

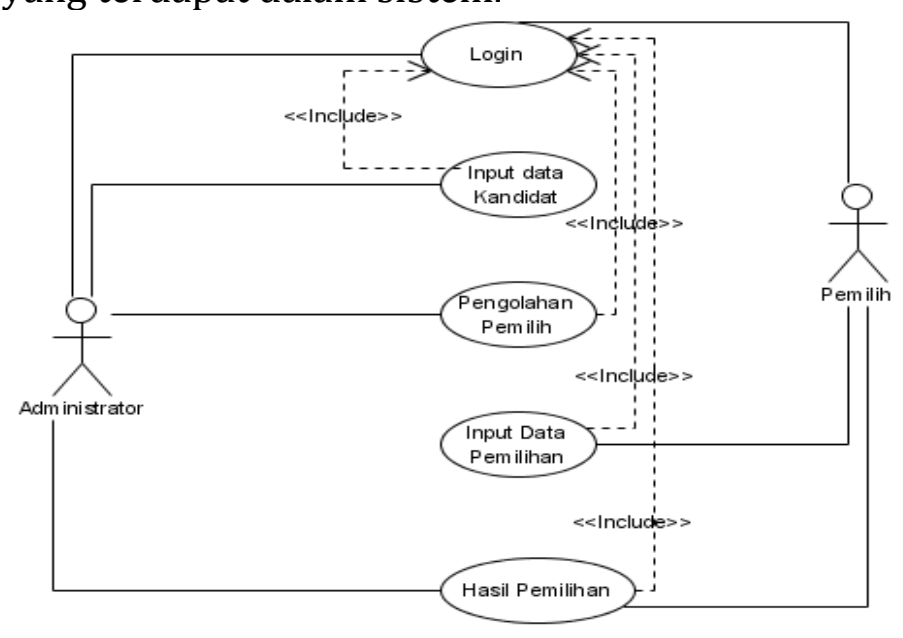

Gambar 2. Use Case Diagram

\subsection{Hasil}

Dari perancangan sistem maka di hasilkan sebuah aplikasi E-Voting system untuk pemilihan Kepala Desa di Desa Rantau Jaya, Kecamatan Karang Jaya, Kabupaten Musi Rawas Utara, berikut ini implementasi dari hasil pengembangan sistem.

\subsection{Pembahasan}

\subsubsection{Halaman Login Admin}

Halaman login admin adalah halaman dimana user admin akan melakukan proses login untuk masuk ke halaman admin, jika proses login berhasil maka akan menuju halaman home admin, jika username dan password salah maka akan menampikan pesan kesalahan, Seperti pada gambar 3. 


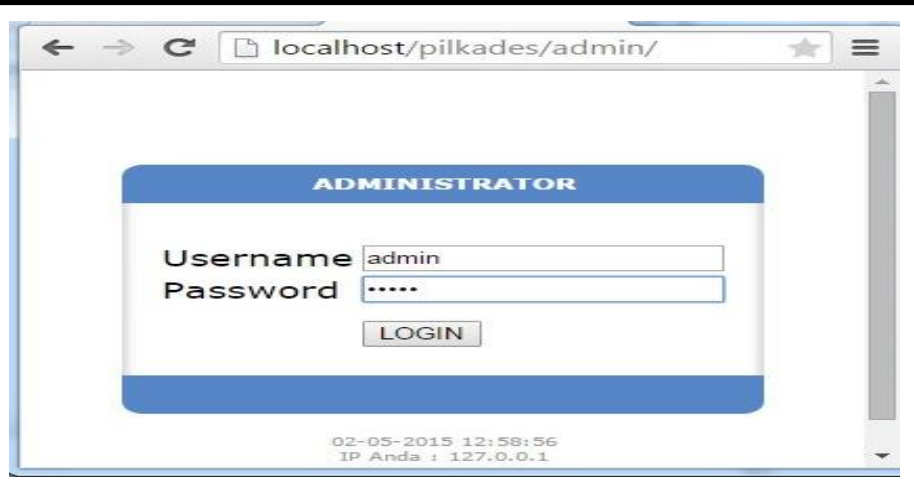

Gambar 3. Halaman Login Admin

\subsubsection{Halaman Home Admin}

Halaman home admin adalah halaman dimana user admin bisa melakukan pengolahan data kandidat, pengolahan data pemilih dan melakukan perubahan pada data admin.

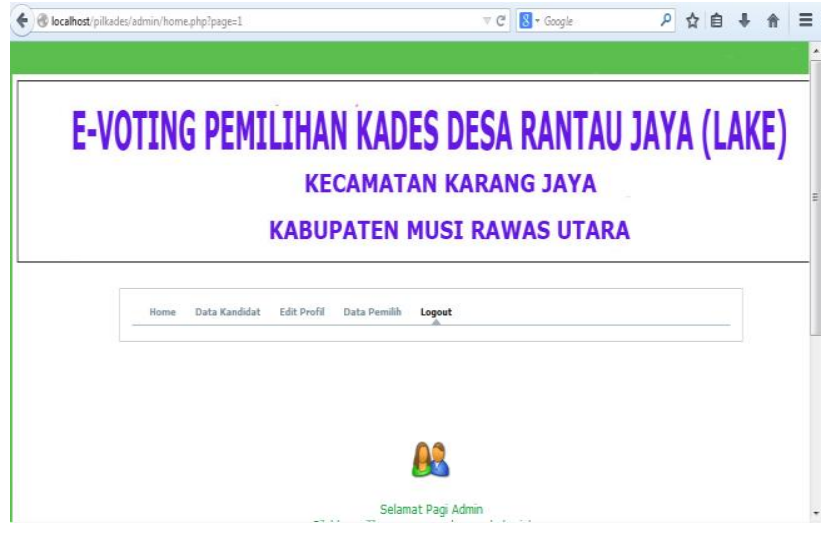

Gambar 4. Halaman Home Admin

\subsubsection{Halaman Pengolahan Data Kandidat}

Di halaman ini admin bisa melakukan penambahan data kandidat, edit data kandidat dan penghapusan dan kandidat.

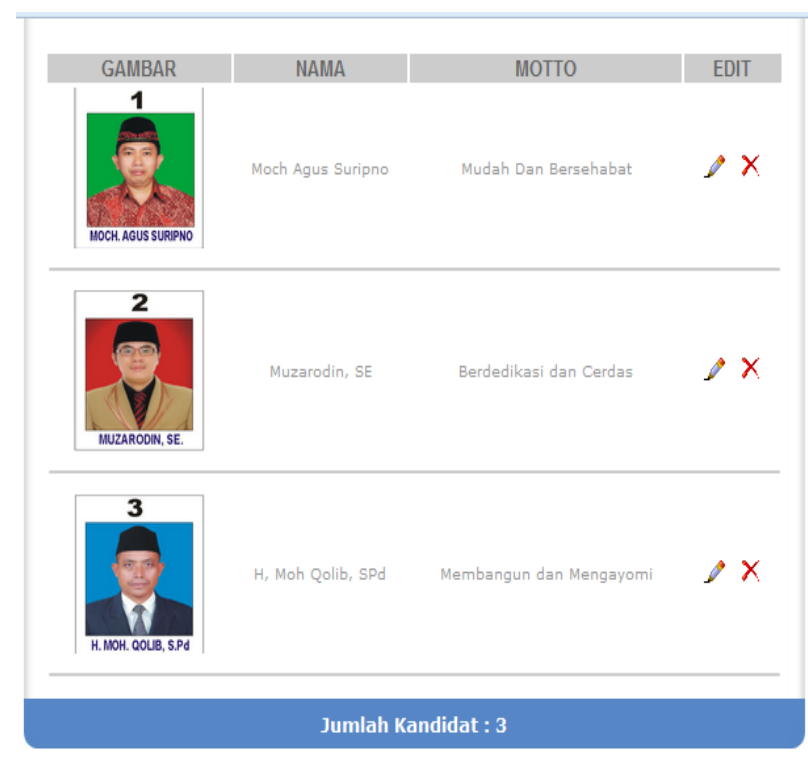

Gambar 5. Halaman Pengolahan Kandidat 


\subsubsection{Halaman Tambah Data Kandidat}

Di halaman ini admin bisa melakukan penambahan data kandidat, jika berhasil maka akan disimpan pada basis data, dijika gagal maka akan menampilkan pesan kesalahan, seperti pada gambar 6.

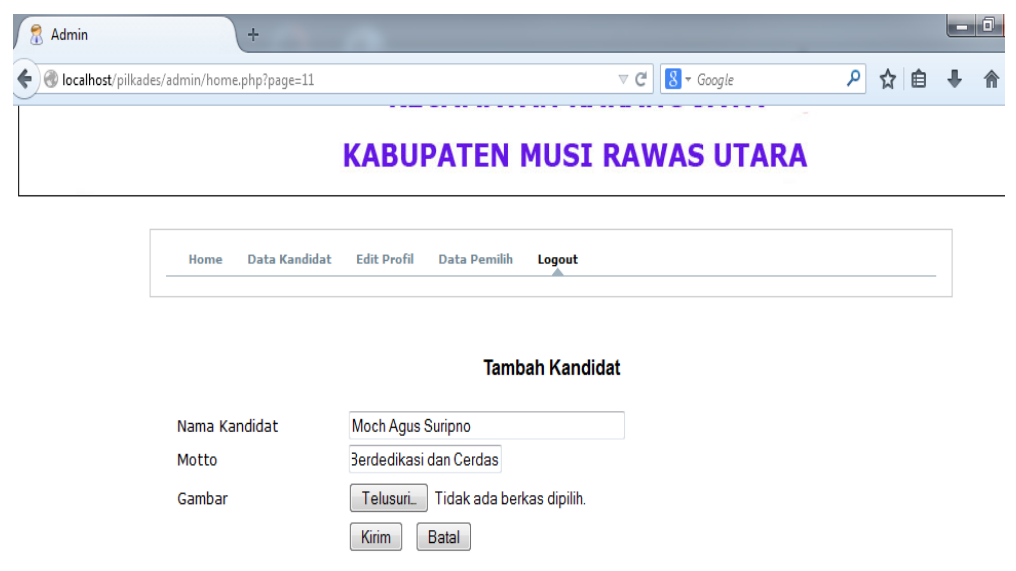

Gambar 6. Halaman Penambahan Kandidat

\subsubsection{Halaman Edit Data Kandidat}

Di halaman ini admin bisa melakukan pengeditan pada data kandidat.

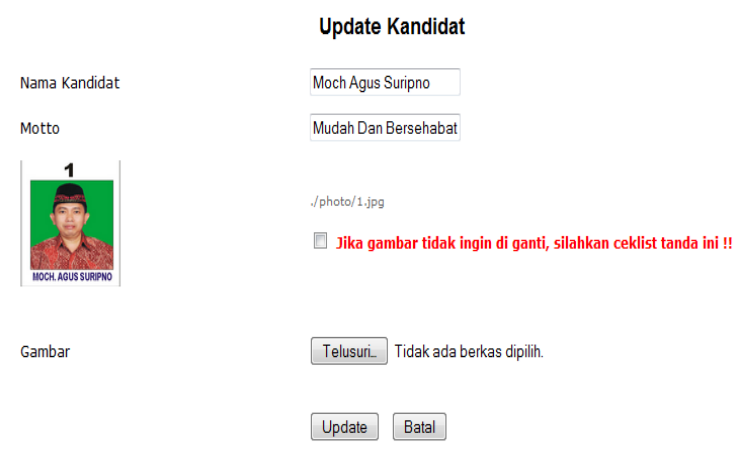

Gambar 7. Halaman Edit Kandidat

\subsubsection{Halaman Hapus Data Kandidat}

Di halaman ini admin bisa melakukan penghapusan pada data kandidat

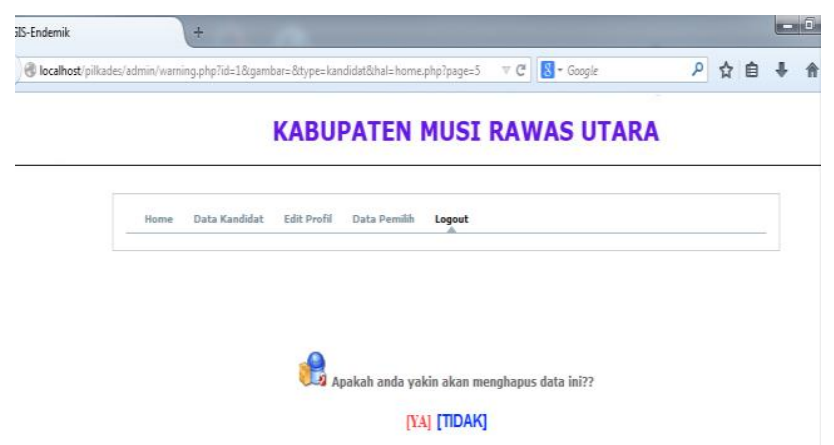

Gambar 8. Halaman Hapus Kandidat

E-Voting Berbasis Website (Harma Oktafia Lingga Wijaya) $\mid 53$ 


\subsubsection{Halaman Pengolahan Data Pemilih}

Di halaman ini admin bisa melakukan penambahan data kandidat, edit data kandidat dan penghapusan dan kandidat, seperti pada gambar 9

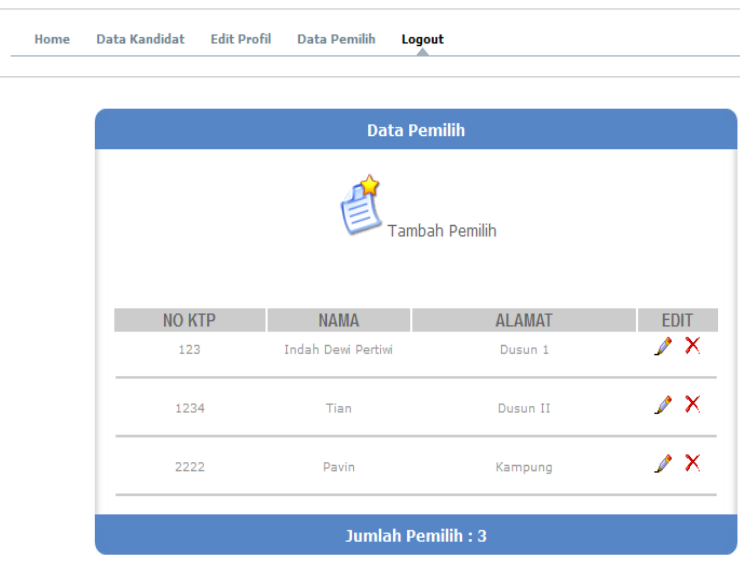

Gambar 9. Halaman Pengolahan Pemilih

\subsubsection{Halaman Tambah Data Pemilih}

Di halaman ini admin bisa melakukan penambahan data pemilih, jika berhasil maka akan disimpan pada basis data, dijika gagal maka akan menampilkan pesan kesalahan, seperti pada gambar 10 .

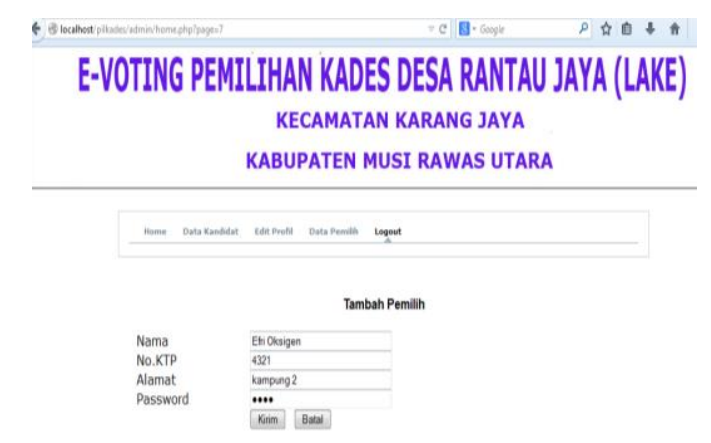

Gambar 10. Halaman Tambah Pemilih

\subsubsection{Halaman Edit Profil Admin}

Di halaman ini admin bisa melakukan pengeditan data profil admin.

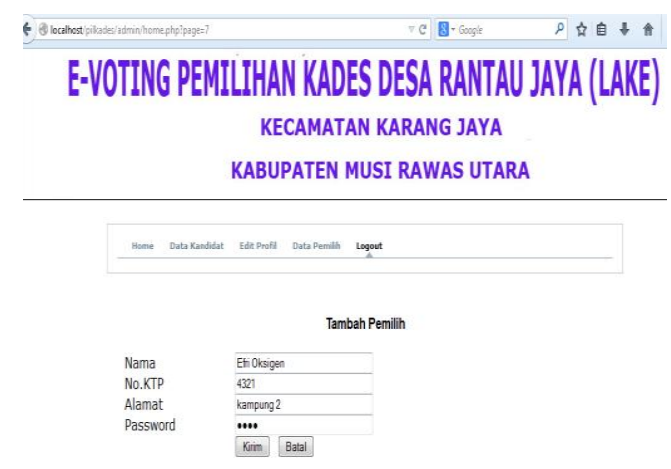

Gambar 11. Halaman Edit Profil Admin 


\subsubsection{Halaman Awal Pemilih}

Halaman ini adalah halaman user pemilih untuk melakukan login agar masuk ke halaman pemilih, dihalaman ini juga di tampilkan data hasil pemilihan sementara, dari pemilih sebelumnya.

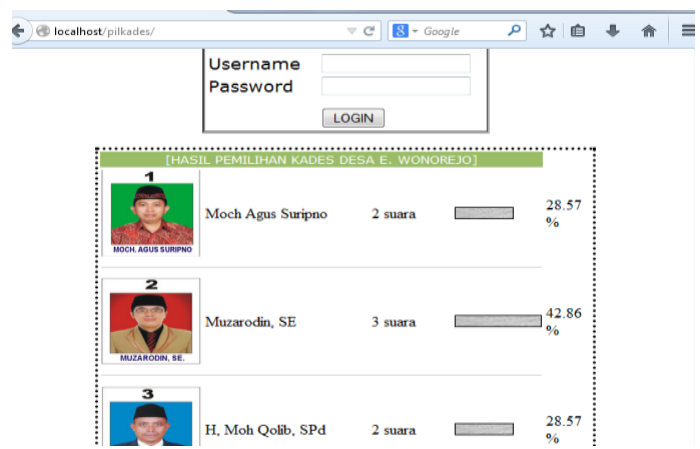

Gambar 11. Halaman Awal Pemilih

\subsubsection{Halaman Login Pemilih}

Halaman ini adalah halaman user pemilih untuk melakukan login, kika proses login berhasil maka akan menuju home pemilih, dan jika tidak berhasil akan menampilkan pesan kesalahan, seperti pada gambar 12

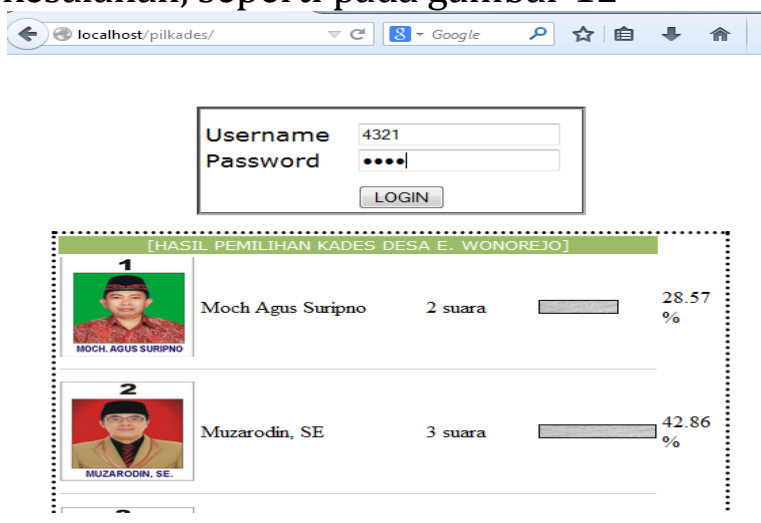

Gambar 12. Halaman Login Pemilih

\subsubsection{Halaman Home Pemilih}

Halaman ini adalah halaman home pemilih, di halaman ini di tampilkan seluruh data kandidat.

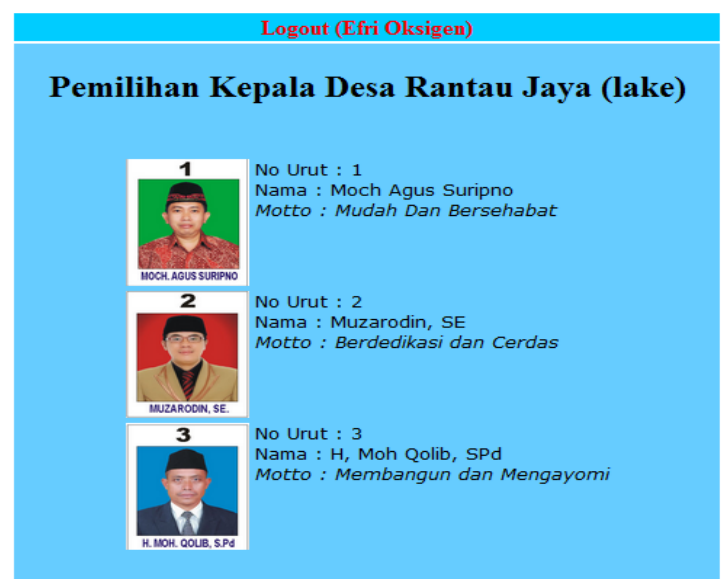

Gambar 13. Halaman Home Pemilih 


\subsubsection{Halaman Voting Kandidat}

Di halaman ini adalah halaman user pemilih untuk melakukan proses voting atau pemilihan salah satu kandidat, seperti pada gambar 14

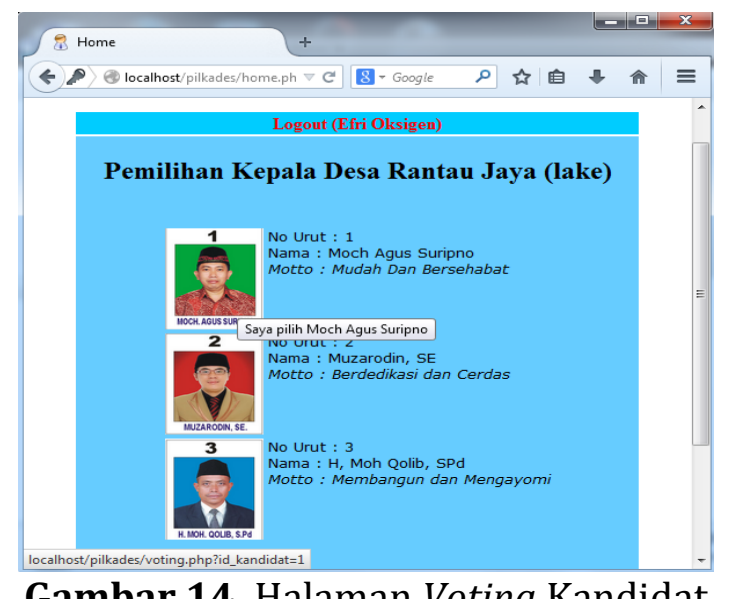

Gambar 14. Halaman Voting Kandidat

Jika user pemilih melakukan pemilihan pada salah satu kandidat maka akan ditampilkan konfirmasi pemilihan, seperti pada gambar 15.

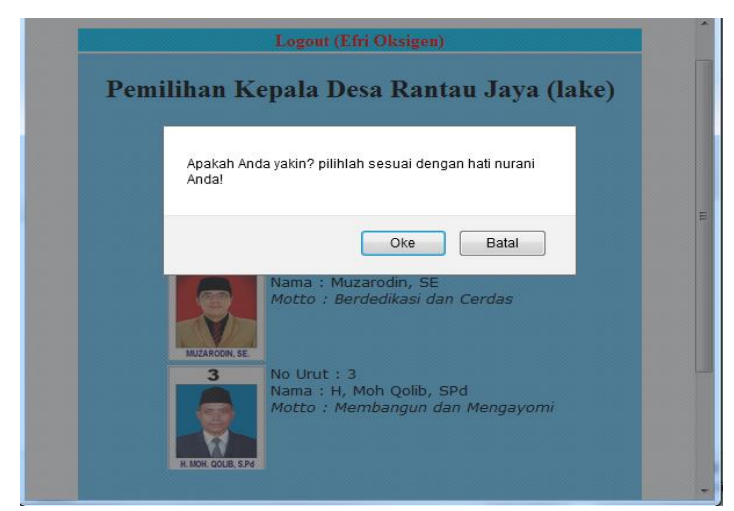

Gambar 16. Halaman Pesan Konfirmasi

Dan jika user pemilih menekan yes maka sistem akan menyimpan data pemilihan dan akan di tampilkan pesan berhasil dari pemilihan, seperti pada gambar 17

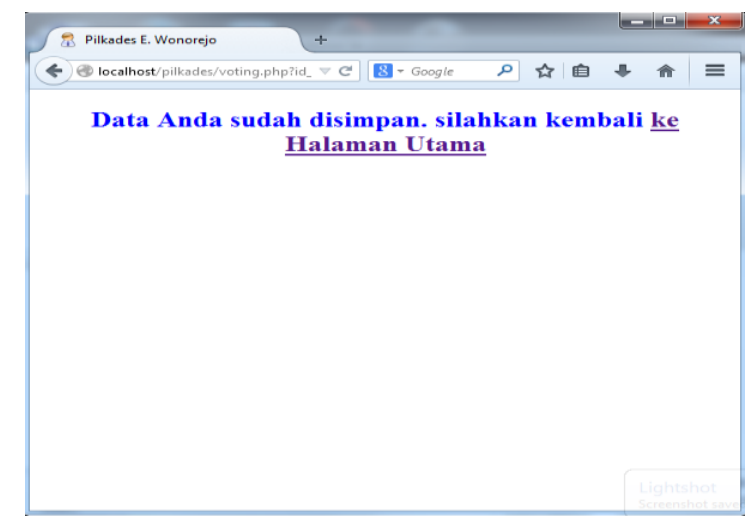

Gambar 17. Halaman Pesan Konfirmasi 


\section{SIMPULAN}

Setelah melalui proses pembangunan dan melihat dari pengujian Aplikasi EVoting Pemilihan Kepala Desa di Desa Rantau Jaya , maka dapat diambil kesimpulan sebagai berikut:

1. Aplikasi E-Voting yang dibangun dapat menjadi alternatif sebagai sarana untuk memmudahkan proses pemilihan Kepala Desa di Desa Rantau Jaya (Lake) dengan mudah, efektif dan akurat.

2. Aplikasi E-Voting dapat mencegah adanya manipulasi suara dari pihak panitia pemilihan karena data pemilihan real time dapat di lihat oleh pemilih.

\section{DAFTAR PUSTAKA}

[1] Al-Bahra bin Ladjamudin. 2015. Analisis dan Desain Sistem Informasi. Graha Ilmu. Yogyakarta.

[2] A.S Rosa dan Salahuddin M, 2011. Modul Pembelajaran Rekayasa Perangkat Lunak (Terstruktur dan Berorientasi Objek), Modula, Bandung.

[3] Alexander F. K. Sibero, 2011, Kitab Suci Web Programing, MediaKom, Yogyakarta

[4] Handoyono, Abdurrosyid.2013. Sistem Pengamanan Data Pemilihan Umum eVoting dengan Menggunakan Algoritma SHA-1. Institut Teknologi Bandung. Bandung

[5] Jogiyanto, 2010, Analisis \& Desain Sistem Informasi, Yogyakarta, Penerbit Andi. Yogyakarta

[6] Madcoms. 2011. Aplikasi Web Database dengan Dreamweaver dan PHP-. MYSQL. Penerbit Andi. Yogyakarta

[7] Mcleod, Raymond, 2011, Sistem Informasi Manajemen, Jakarta, PT. Prenhallindo.

[8] Peraturan Menteri Dalam Negeri Republik Indonesia Nomor 112 Tahun 2014 Tentang Pemilihan Kepala Desa. Depdagri. Jakarta.

[9] Pressman, Roger. 2010. Software Engineering: A Practitioner's Approach, Edisi ke 6, New York.

[10] Saputra, Agus. 2011. Pemrograman CSS Untuk Pemula. Jakarta : PT. Gramedia

[11] Sekretariat Kabinet Republik Indonesia. BPPT Sukses Uji Coba E-voting Berbasis E-KTP di Jembrana, Bali. 2013. http://setkab.go.id/berita-9725-bpptsukses-uji-coba-e-voting-berbasis-e-ktp-di-jembrana-bali.html. 20 Maret 2016.

[12] Wahana Komputer. 2010. The Best Encryption Tools. Elexmedia komputindo. Jakarta

[13] Whitten,et al., 2014, Metode Desain dan Analisis Sistem, Andi, Jakakarta 